HELMINTHOLOGIA, 53, 1: 14 - 23, 2016

\title{
Heavy metal intoxication compromises the host cytokine response in Ascaris suum model infection
}

\author{
E. DVOROŽŇÁKOVÁ ${ }^{*}$, M. DVOROŽŇÁKOVÁ2 J. ŠOLTYS ${ }^{1}$
}

\begin{abstract}
${ }^{1}$ Institute of Parasitology of the Slovak Academy of Sciences, Hlinkova 3, 04001 Košice, Slovak Republic, *E-mail: dvoroz@saske.sk;
\end{abstract} ${ }^{2}$ Eastern Slovak Institute for Cardiovascular Diseases, Košice, Slovak Republic

\section{Article info}

Received October 13, 2015 Accepted November 10, 2015

\begin{abstract}
Summary
Lead $(\mathrm{Pb})$, Cadmium $(\mathrm{Cd})$ and Mercury $(\mathrm{Hg})$ are recognized for their deleterious effect on the environment and immunity where subsequently compromised immune response affects the susceptibility to the potential parasitic infections. This study examined the host cytokine response after heavy metal intoxication $(\mathrm{Pb}, \mathrm{Cd}$, and $\mathrm{Hg}$ ) and subsequent Ascaris suum infection in BALB/c mice. $\mathrm{Pb}$ modulated murine immune response towards the Th2 type of response (delineated by IL-5 and IL-10 cytokine production) what was also dominant for the outcome of $A$. suum infection. Chronic intoxication with $\mathrm{Pb}$ caused a more intensive development of the parasite infection. Cd stimulated the Th1 immune response what was associated with increase in IFN-y production and reduction of larvae present in the liver of intoxicated mice. The larval burden was also low in mice intoxicated with $\mathrm{Hg}$. This was probably not related to the biased Th1/Th2 type of immune response, but rather to the bad host conditions caused by mercury toxicity and high level of pro-cachectic cytokine TNF-a.

Keywords: heavy metals; Ascaris suum; cytokines; Th1/Th2 immune response; mice
\end{abstract}

\section{Introduction}

Heavy metals are biologically nondegradable environmental pollutants that can negatively affect the health of human and animals prompting carcinomas, hematotoxicity, allergy and immunotoxicity (Järup, 2003). They accumulate within the food chain what results in serious ecological and health hazards. Exposure of organisms to the heavy metal ions impairs hosts immunocompetence and increases susceptibility to the infections. Heavy metals also affect the cell physiology and modulate immune system responses (Valko et al., 2005; Holmes et al., 2009; Jomova \& Valko, 2011; Hemdan et al., 2013; Pollard \& Kono, 2013; Dvorožnáková \& Jalčová, 2013).

Due to high abundance of industrial heavy metals in exposed areas small mammals migrating in affected territories are suitable bioindicators of anthropogenic environmental pollution. Survival of the small mammals allows identify local environmental problems such as long-term effect of heavy metals bioaccumulation and determine health defects caused by ongoing environmental pollution (Flickinger \& Nichols, 1990; Tersago et al., 2004).

Environmental pollution can affect parasitism (Lafferty \& Kuris, 1999) where parasites can be used as sentinel organisms i.e. indicators of environmental pollutants accumulation. On the other hand parasites can interfere with bioindicative potential of hosts due to their effect on physiology and behaviour. It may trigger a false positive or negative assessment of the environmental contamination. Therefore it is required to study the parasite-host interactions in relation to the heavy metal immunotoxicity.

The immunotoxicity of heavy metals and their modulation of parasite-host interactions were tested on model of Ascaris suum helminth infection. Ascariosis is a widespread parasitosis in which the roundworm Ascaris lumbricoides infects about 1 billion people 
worldwide, and also affects innumerable pigs across the globe (Betson et al., 2014). Interference of this nematode species with heavy metals is very likely. Contingent upon epidemiological potential and local phylogeography the natural cross-transmission of Ascaris spp. between pig and human hosts takes place in developing and developed countries (Šnábel et al., 2012; Betson et al., 2014). The use of a murine experimental model for Ascaris infection provides detailed information about the biology at early stage of infection and larval migration what is difficult to follow in naturally occurring infections. Moreover, this experimental model mimics the biological events that take place in natural host. The developmental stages of above mentioned parasite species are able to survive in external environment for relatively long time and with a such high worldwide prevalence may well have contact with heavy metals. In fact the circulation of Ascaris in polluted areas is more often (Kutalek et al., 2010; Ngui et al., 2012). Mouse experimental studies focused on the host immune responses can substantiate the positive or negative effects of polluted environment on development of a host immune response as well as the influence of heavy metals on host immune system i.e. immunotoxicity and parasite pathogenicity.

The aim of this study was to examine the immunotoxic effect of heavy metals (lead, cadmium and mercury) on cytokine production and development of the Th1/Th2 type of response during subsequent murine Ascaris suum infection.

\section{Materials and Methods}

\section{Heavy metal intoxication}

Mice were exposed to the salts of lead or cadmium dissolved in drinking water and mercury dissolved in aqua pro injectione at the following concentrations and administrations:

Lead: $\mathrm{Pb}\left(\mathrm{CH}_{3} \mathrm{COO}\right)_{2}$ (Sigma-Aldrich, Hamburg, Germany) 100 mg/l, provided in drinking water ad libitum;

Cadmium: $\mathrm{CdCl}_{2}$ (Sigma-Aldrich, Hamburg, Germany) 100 mg/l, provided in drinking water ad libitum;

Mercury: $\mathrm{HgCl}_{2}$ (Sigma-Aldrich, Hamburg, Germany) $0.2 \mathrm{mg} / \mathrm{kg}$ of body weight, injected subcutaneously (s.c.) at each day throughout the experiment.

\section{Parasite isolation}

The embryonated Ascaris suum eggs were prepared by a modified method according to Boes et al. (1998). Adult worms were obtained from pigs at a Hrabkov slaughterhouse (Slovakia). The eggs were than isolated from the distal end of the uterus $(2 \mathrm{~cm})$ by a gentle mechanical maceration. Purified eggs were cultured in $0.1 \mathrm{~N} \mathrm{NaOH}$ at room temperature and protected from light until they reached the infective third-stage larvae $(\mathrm{L} 3)$. During 5 weeks incubation the egg suspensions were oxygenated three times per week by stirring. Eggs embryonation was evaluated microscopically on weekly basis starting from day 14 . Finally, the embryonated $A$. suum eggs were stored in $0.1 \mathrm{~N} \mathrm{NaOH}$ at $4-6{ }^{\circ} \mathrm{C}$ and regularly oxygenated until the infection of experimental animals.

Infection

Each mouse received a dose of 1000 infective $A$. suum eggs in $0.2 \mathrm{ml}$ of phosphate buffered saline (PBS) per os. Due to a higher infectivity rate of $A$. suum larvae between $100^{\text {th }}$ and $200^{\text {th }}$ days of culture a 120 days old $A$. suum eggs culture was used (Gazzinelli-Guimarães et al., 2013).

\section{Experimental design}

Three experiments were carried out on pathogen-free 8 weeks old male BALB/c mice (VELAZ, Prague, Czech Republic; $n=180$ ) weighting $18-20 \mathrm{~g}$. Mice were kept in controlled environment under a 12-h light/dark regimen at room temperature $\left(22-24^{\circ} \mathrm{C}\right)$ with $56 \%$ humidity and fed with commercial diet (MP-OŠ-06, MIŠKO, Snina, Slovak Republic). Water was provided ad libitum. The experimental protocol complied with current Slovak ethics law and was approved by the Animal Care Committee of the Institute of Parasitology SAS and the State Veterinary and Food Administration of the Slovak Republic (No. Ro-1888/10-221a).

Three individual experiments with heavy metals intoxicated mice were performed.

Experiment I. - Chronic intoxication with lead $(\mathrm{Pb})+$ infection A. suum.

Experiment II. - Chronic intoxication with cadmium (Cd) + infection A. suum.

Experiment III. - Chronic intoxication with mercury $(\mathrm{Hg})+$ infection A. suum.

Animals in each independent experiment were divided randomly into four groups as follows:

Group $1(n=18)$ - control mice without intoxication and infection.

Group $2(\mathrm{n}=18)$ - mice intoxicated with $\mathrm{Pb}$ or $\mathrm{Cd}$ or $\mathrm{Hg}$.

Group $3(n=12)$ - mice infected with 1000 eggs of $A$. suum/mouse at day 21 of the experiment.

Group 4 ( $\mathrm{n}=12$ ) - mice intoxicated with $\mathrm{Pb}$ or $\mathrm{Cd}$ or $\mathrm{Hg}$ and subsequently infected with $A$. suum on day 21 of the experiment.

Samples of the spleen, liver, lungs, kidneys and muscles were obtained on days $0,7,14,21,25$ (infected groups 3, 4), 28 and 35. Three mice were examined on each sample day and from each experimental group.

\section{Detection of heavy metals in tissues}

Murine tissue samples (liver, kidneys, muscle) for detection of lead and cadmium content were mineralized with $\mathrm{HNO}_{3}$ and $\mathrm{H}_{2} \mathrm{O}_{2}$ in Microwave oven MLS 1200 (Milestone, Sorisole, Italy). The concentrations of $\mathrm{Pb}$ and $\mathrm{Cd}$ were quantified by Inductive Couple Plasma-OES (Perkin Elmer Instrument USA, Optima 200 DV, Richmond, California) using the wavelength 220.353 and 228.802 $\mathrm{nm}$ for $\mathrm{Pb}$ and $\mathrm{Cd}$, respectively. The concentration of mercury was determined directly by a single-purpose atomic absorption spectrometer AMA 254 (Advanced Mercury Analyser, Altec, Prague, Czech Republic). 
Larvae recovery from the liver and lungs

Surgically removed livers or lungs were cut into small pieces. Then packed in sterile gauze and placed at the top of a conic tube filled with warm phosphate buffered saline (PBS). Living larvae were recovered from tissues in Baermann's apparatus after overnight incubation at $37^{\circ} \mathrm{C}$. The larval suspensions were centrifuged at $200 \mathrm{~g}$ for $5 \mathrm{~min}$ and the volume reduced by aspiration to $3-5 \mathrm{ml}$ (depending on the amount of sediment). The number of larvae was counted microscopically (Leica Microsystems, Wetzlar, Germany).

\section{Cytokine assay}

The capture ELISA was employed to determine the concentration of in vitro cytokine production in splenocytes (Dvorožňáková et al., 2011). Splenocytes for cytokine production were aseptically resuspended to the final concentrations of $10^{7} \mathrm{cell} / \mathrm{s} / \mathrm{ml}$ in RPMl 1640 medium (Sigma-Aldrich, Germany) and incubated with $10 \mu \mathrm{g} / \mathrm{ml}$ of Concanavalin A (Con A; Sigma-Aldrich, Hamburg, Germany) at $37{ }^{\circ} \mathrm{C}$ in $5 \% \mathrm{CO}_{2}$ and $85 \%$ humidity. Cell supernatants were harvested after 72 hours incubation and stored at $-80{ }^{\circ} \mathrm{C}$. Interferon- $y$, tumour necrosis factor-a (IFN- $y$, TNF- $\alpha$ ), interleukin-5 and interleukin-10 (IL-5, IL-10) were used as marker cytokines for the assessment of the Th1 and Th2 responses development. Purified anti-cytokine monoclonal antibodies (capture antibodies) which were coated overnight at $4{ }^{\circ} \mathrm{C}$ onto 96 microwell plates (Nunc, Thermo Fisher Scientific, Roskilde, Denmark). The pairs of cytokine-specific monoclonal antibodies used were: R4-6A2 and XMG1.2 for IFN-p; G281-2626 and MP6XT3 for TNF-a; TRFK5 and TRF4 for IL-5; JES5-2A5 and SXC-1 for IL-10 (BD Biosciences PharMingen, Erembodegem, Belgium). After the plates washings non-specific bonds were blocked for 1 hour at room temperature with $0.5 \%$ skimmed milk in PBS. Following the subsequent wash, cytokines standards and samples were bound overnight at $4{ }^{\circ} \mathrm{C}$. Murine recombinant IFN- $\gamma$, TNF-a, IL-5 and IL-10 (BD Biosciences PharMingen, Erembodegem, Belgium) in concentration range $0.015-8 \mathrm{ng}$ were used as standards. Captured cytokine proteins were detected with biotin-conjugated anti-cytokine monoclonal antibodies (1 hour at room temperature). After the plate washings a streptavidin conjugated with peroxidase (MP Biomedicals, USA) was added and incubated again for 1 hour at room temperature. After repeated washing 2,2'-azino-bis(3-ethylbenzothiazoline-6-sulfonic (Sigma-Aldrich, Hamburg, Germany) substrate, at concentration of $1 \mathrm{mg} / \mathrm{ml}$ in citrate buffer ( $\mathrm{pH} 4.3$ ) with $0.03 \% \mathrm{H}_{2} \mathrm{O}_{2}$ was used to visualize the reactions. Colour reaction was stopped with $20 \%$ sodium dodecyl sulphate solution dissolved in $50 \%$ N,N-dimethylformamide (SDS/ DMF, both Sigma-Aldrich, Hamburg, Germany). Cytokine concentrations were measured with Multiskan Reader at $405 \mathrm{~nm}$ (Thermo Fisher Scientific, Vantaa, Finland). The detection limit for the cytokine assays was $40 \mathrm{pg} / \mathrm{ml}$.

\section{Statistical evaluation}

Statistical differences were assessed by Two-way ANOVA followed by Bonferroni post-tests using GraphPad Prism version 5.00 for Windows (GraphPad Software, San Diego California USA, www. graphpad.com). Values of $P<0.05$ were considered significant what allowed comparison between each experimental groups and at

Table 1. Heavy metal concentrations in tissues of mice intoxicated with heavy metals (lead Pb, cadmium Cd, mercury $\mathrm{Hg}$ ) and infected with $A$. suum

\begin{tabular}{|c|c|c|c|c|c|}
\hline Heavy metal & Experimental groups & $\begin{array}{l}\text { Days of experiment } \\
\text { (Days post infection) }\end{array}$ & $\begin{array}{l}\text { liver (mg/kg) } \\
\text { (mean } \pm S . D .)\end{array}$ & $\begin{array}{l}\text { kidneys (mg/kg) } \\
\text { (mean } \pm \text { S.D.) }\end{array}$ & $\begin{array}{c}\text { muscles }(\mathrm{mg} / \mathrm{kg}) \\
(\text { mean } \pm \text { S.D.) }\end{array}$ \\
\hline \multirow[t]{4}{*}{$\mathrm{Pb}$} & control & 0 & $0.12 \pm 0.06$ & $0.22 \pm 0.08$ & $0.16 \pm 0.09$ \\
\hline & intoxication (before infection) & 21 & $0.51 \pm 0.18$ & $\# 0.71 \pm 0.05$ & $0.71 \pm 0.18$ \\
\hline & intoxicated & 35 & $0.27 \pm 0.03$ & $0.34 \pm 0.04$ & $0.48 \pm 0.04$ \\
\hline & intoxicated+infected & 35 (14 p.i.) & $0.36 \pm 0.14$ & $0.44 \pm 0.02$ & $0.59 \pm 0.14$ \\
\hline \multirow[t]{4}{*}{$\mathrm{Cd}$} & control & 0 & $0.02 \pm 0.01$ & $0.05 \pm 0.01$ & $0.03 \pm 0.01$ \\
\hline & intoxication (before infection) & 21 & $\# 0.61 \pm 0.09$ & $\#^{\# 0.75} \pm 0.05$ & $0.04 \pm 0.01$ \\
\hline & intoxicated & 35 & $\# 0.87 \pm 0.57$ & \#\#2.06 \pm 0.32 & $0.03 \pm 0.01$ \\
\hline & intoxicated+infected & 35 (14 p.i.) & $0.35 \pm 0.30$ & *1.17 \pm 0.29 & $0.05 \pm 0.01$ \\
\hline \multirow[t]{4}{*}{$\mathrm{Hg}$} & control & 0 & $1.03 \pm 0.35$ & $0.98 \pm 0.39$ & $0.03 \pm 0.01$ \\
\hline & intoxication (before infection) & 21 & $\# 10.44 \pm 0.29$ & $\# 160.56 \pm 12.78$ & $\# 0.67 \pm 0.23$ \\
\hline & intoxicated & 35 & \#\#11.48 \pm 2.89 & \#\#\# 75.48 \pm 15.25 & $\# 0.46 \pm 0.28$ \\
\hline & intoxicated+infected & 35 (14 p.i.) & $9.57 \pm 4.12$ & $90.68 \pm 1.57$ & $0.52 \pm 0.18$ \\
\hline
\end{tabular}

$\#(P<0.05 ; \#(P<0.01)$; \#\#\#(P<0.0001) statistically significant differences between control and heavy metal's intoxication;

* $(P<0.05)$ statistically significant differences between heavy metal's intoxication and heavy metal's intoxication in combination with $A$. suum infection. 
Table 2. Parasite larval burden in mice intoxicated with heavy metals (lead $\mathrm{Pb}$, cadmium $\mathrm{Cd}$, mercury $\mathrm{Hg}$ ) and infected with $A$. suum

\begin{tabular}{|c|c|c|c|c|c|}
\hline \multirow{2}{*}{$\begin{array}{l}\text { Heavy metal } \\
\text { intoxication }\end{array}$} & \multirow{2}{*}{$\begin{array}{l}\text { Days of experiment } \\
\text { (Days post infection) }\end{array}$} & A.suum & \multicolumn{3}{|c|}{ intoxication + A.suum } \\
\hline & & $\begin{array}{c}\text { liver } \\
\text { (mean } \pm \text { S.D.) }\end{array}$ & $\begin{array}{c}\text { lungs } \\
\text { (mean } \pm \text { S.D.) }\end{array}$ & $\begin{array}{c}\text { liver } \\
\text { (mean } \pm S . D .)\end{array}$ & $\begin{array}{c}\text { lungs } \\
\text { (mean } \pm S . D .)\end{array}$ \\
\hline \multirow[t]{2}{*}{$\mathrm{Pb}$} & 25. (4. p.i.) & $195.0 \pm 43.0$ & & $250.6 \pm 28.7$ & \\
\hline & 28. (7. p.i.) & $3.3 \pm 1.5$ & $66.7 \pm 15.9$ & $2.6 \pm 3.8$ & $86.3 \pm 17.5$ \\
\hline \multirow[t]{2}{*}{$\mathrm{Cd}$} & 25. (4. p.i.) & $225.5 \pm 57.3$ & & $* 87.3 \pm 42.2$ & \\
\hline & 28. (7. p.i.) & $7.3 \pm 3.5$ & $31.7 \pm 23.6$ & $2.3 \pm 4.0$ & $33.3 \pm 2.1$ \\
\hline \multirow[t]{2}{*}{$\mathrm{Hg}$} & 25. (4. p.i.) & $179.3 \pm 40.5$ & & ${ }^{*} 70.0 \pm 24.0$ & \\
\hline & 28. (7. p.i.) & $4.3 \pm 3.2$ & $25.7 \pm 6.1$ & $4.3 \pm 4.2$ & *7.3 \pm 3.2 \\
\hline
\end{tabular}

* $(\mathrm{P}<0.05)$ statistically significant differences between $A$. suum infection and heavy metal's intoxication in combination with $A$. suum infection

each time point (control versus heavy metal without parasitic infection and $A$. suum infection vs heavy metal with $A$. suum infection).

\section{Results}

Heavy metal distribution

The heavy metal accumulation was determined in the liver, kidneys and muscles of intoxicated mice as well as in mice intoxicated and subsequently infected with $A$. suum (Table 1). Heavy metals showed a higher affinity to the liver and kidneys. Except of
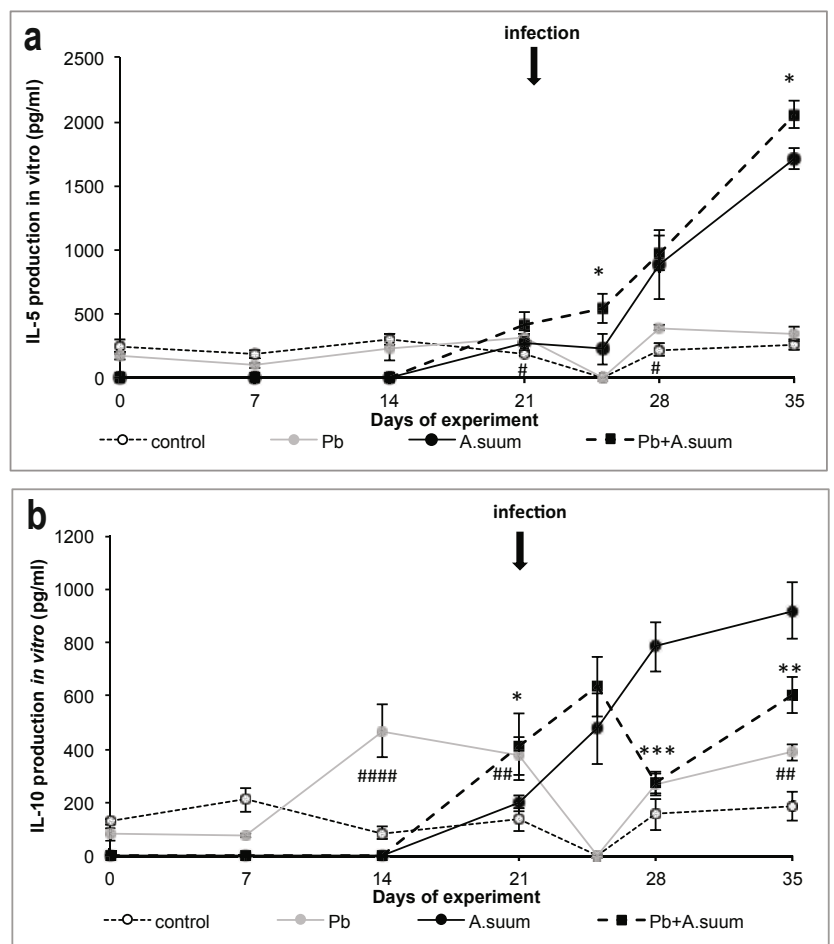

lead the lowest metal accumulation was detected in the muscles. Lead concentration peaked at week 3 of the intoxication and then gradually decreased by week 5 in all examined organs. The parasite infection did not affect lead content in the tissues. Increase in cadmium concentration was time dependent and maximal values were found in kidneys at the end of experiment. A. suum infection contributed to the decrease cadmium deposition in the kidneys $(\mathrm{P}<0.01)$ and the liver on week 5 . Mercury concentration was also increased during liver intoxication. The kidneys were the main organ for mercury accumulation. The content of mercury in kidneys
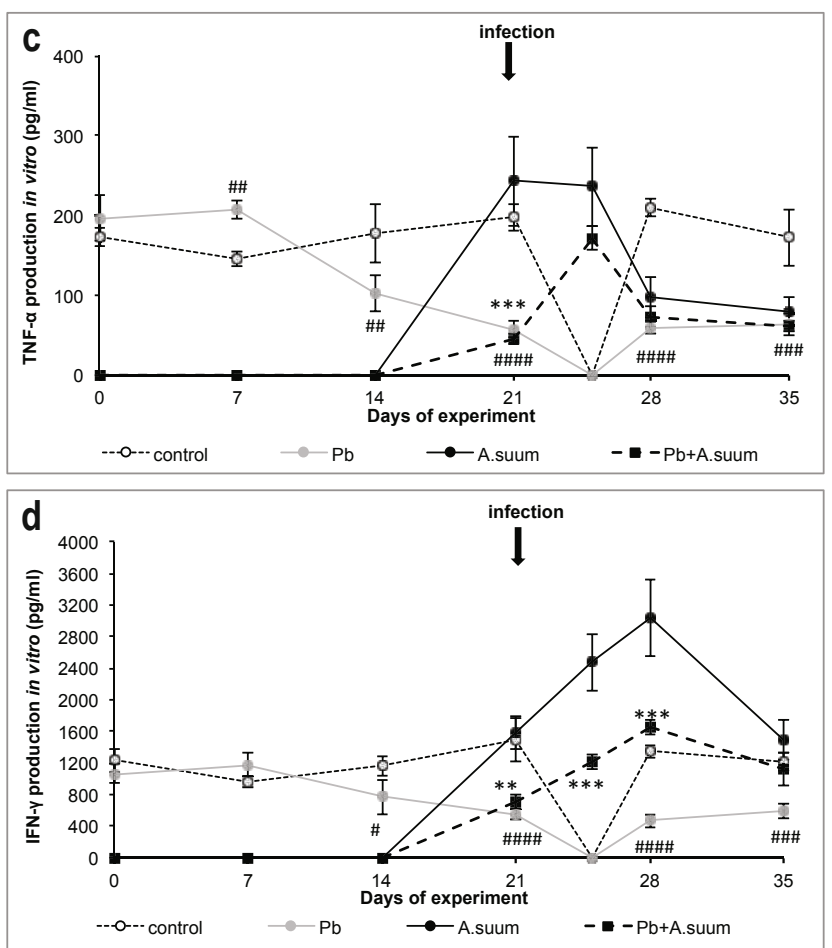

Fig. 1. Cytokine production (a) IL-5, (b) IL-10, (c) TNF-a, (d) IFN-y by mouse splenocytes intoxicated with lead (Pb) and infected with $A$. suum.

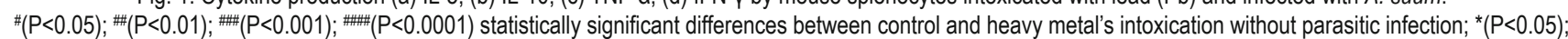
${ }^{* *}(P<0.01) ;{ }^{* * *}(P<0.001)$ statistically significant differences between $A$. suum infection and heavy metal's intoxication in combination with $A$. suum infection. 
peaked at week 3 and decreased by week 5 . The parasite infection did not affect mercury distribution in examined organs.

\section{Lead and Ascaris suum infection}

\section{Parasite burden}

In comparison with the only infected mice without heavy metals intoxication (Table 2) the larval recoveries from the liver and lungs were increased in mice intoxicated with $\mathrm{Pb}$. However, no significant differences were found. Mice intoxicated with $\mathrm{Pb}$ showed slight weight loss (unpublished data).

\section{IL-5 and IL-10 production}

The production of IL-5 by splenocytes (Fig. 1a) was stimulated during $\mathrm{Pb}$ intoxication after 3 weeks of administration $(P<0.05)$. A. suum infection induced a sharp growth in IL-5 synthesis at day 7 post infection (p.i.), i.e. experimental day 28. Similar dynamics occurred in mice with or without $\mathrm{Pb}$ intoxication. However, higher values were detected in group with $\mathrm{Pb}$ intoxication and $A$. suum infection. The production of IL-10 (Fig. 1b) augmented two $(P<0.0001)$ as well as three and five weeks after the $\mathrm{Pb}$ intoxication $(\mathrm{P}<0.01)$. A. suum infection increased the level of $\mathrm{IL}-10$ within one week p.i. $(P<0.001)$ and high IL-10 production persisted also during a second week of the infection $(P<0.01)$. In mice intoxicated with $\mathrm{Pb}$ and subsequently infected with $A$. suum, the IL-10 values exceeded the level observed in infected mice without $\mathrm{Pb}$ intoxication $(P<0.05)$ at the beginning of the infection.
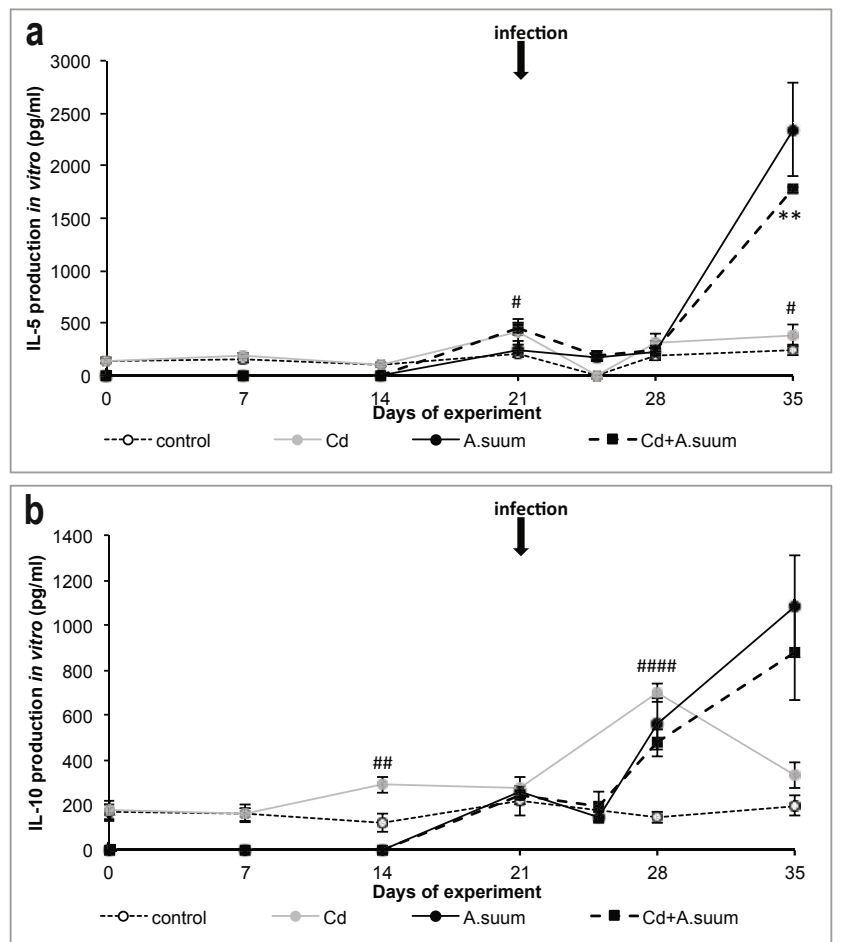

TNF- $\alpha$ and IFN- $\gamma$ production

The TNF- $\alpha$ and IFN- $y$ production (Fig. 1c, d) was suppressed from week 2 of $\mathrm{Pb}$ intoxication $(\mathrm{P}<0.01)$ until the end of the experiment ( 3 and 4 weeks, $P<0.0001$; and 5 weeks, $P<0.001$ ). A. suum infection suppressed the TNF-a production below the level of healthy uninfected control. Pro-inflammatory IFN- $y$ was stimulated for one week after $A$. suum infection. $\mathrm{Pb}$ intoxication in infected mice inhibited $(\mathrm{P}<0.001)$ the IFN-y production, and its level approximated to the level in control group of mice.

\section{$\underline{\text { Cadmium and Ascaris suum infection }}$}

\section{Parasite burden}

The total number of $A$. suum larvae recovered from the liver of mice intoxicated with $\mathrm{Cd}$ (Table 2 ) was significantly reduced $(\mathrm{P}<0.05)$ at day 4 post infection (p.i.). However, the number of larvae in the lungs was not affected by $\mathrm{Cd}$ intoxication. Mice intoxicated with $\mathrm{Cd}$ were in good condition and increase in the body weight was observed when compared with control (unpublished data).

\section{IL-5 and IL-10 production}

The IL-5 production (Fig. 2a) was not markedly influenced by $\mathrm{Cd}$ whereas $A$. suum infection caused abundant modulation in IL-5 synthesis at week 2 p.i. (i.e. experimental day 35). The increase in IL-10 level (Fig. 2b) was found in mice intoxicated with $\mathrm{Cd}$ after the $2^{\text {nd }}$ week of the intoxication $(P<0.05)$ with a peak reached at $4^{\text {th }}$ week $(P<0.0001)$. A. suum infection induced a sharp and con-
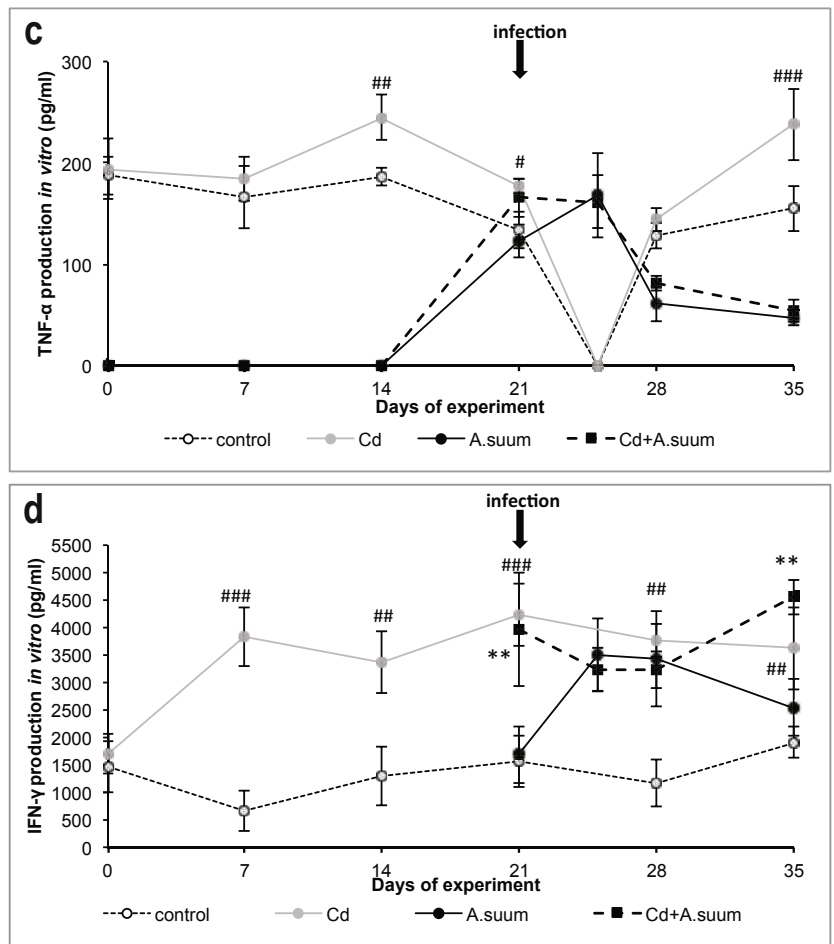

Fig. 2. Cytokine production (a) IL-5, (b) IL-10, (c) TNF-a, (d) IFN-y by mouse splenocytes intoxicated with cadmium (Cd) and infected with $A$. suum. $\#(P<0.05) ; \#(P<0.01) ;{ }^{\#}(P<0.001) ; \ldots(P<0.0001)$ statistically significant differences between control and heavy metal's intoxication without parasitic infection; ${ }^{* *}(P<0.01)$ statistically significant differences between $A$. suum infection and heavy metal's intoxication in combination with $A$. suum infection. 

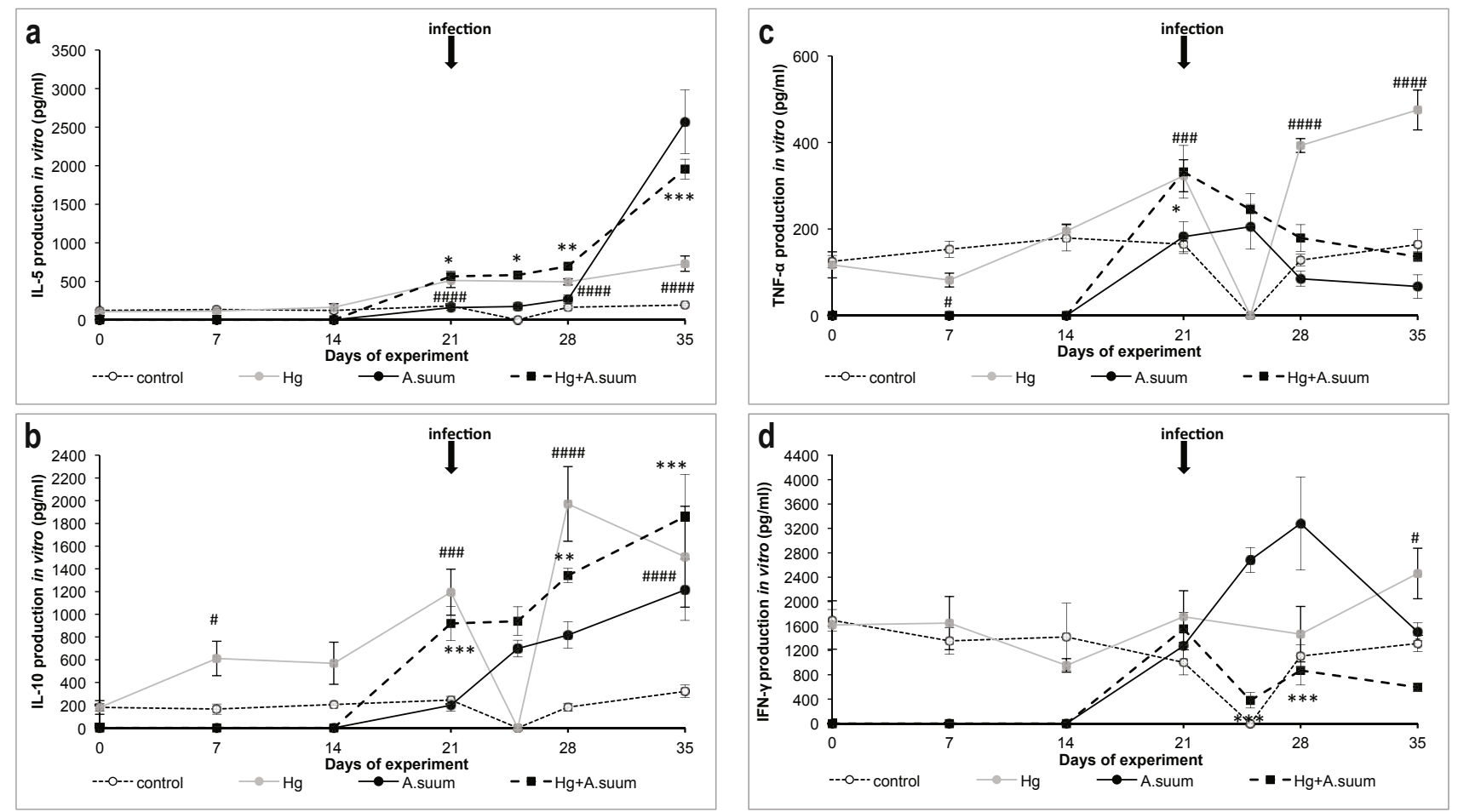

Fig. 3. Cytokine production (a) IL-5, (b) IL-10, (c) TNF-a, (d) IFN-y by moue splenocytes intoxicated with mercury (Hg) and infected with $A$. suum. $\#(P<0.05) ; \#(P<0.001) ; \ldots+(P<0.0001)$ statistically significant differences between control and heavy metal's intoxication without parasitic infection; ${ }^{*}(P<0.05) ;{ }^{* *}(P<0.01) ;{ }^{* * *}(P<0.001)$ statistically significant differences between $A$. suum infection and heavy metal's intoxication in combination with $A$. suum infection.

tinuous growth in IL-10 production from day 5 p.i. Though, this increase was not affected by $\mathrm{Cd}$.

\section{TNF- $\alpha$ and IFN- $\gamma$ production}

TNF-a synthesis was increased by $C d$ intoxication $(P<0.01$; $\mathrm{P}<00.05 ; \mathrm{P}<0.001$ ) throughout the experiment (Fig. 2c). A. suum infection suppressed the TNF-a production below the levels found in control of uninfected and $\mathrm{Cd}$ intoxicated mice from day $7 \mathrm{p.i.}$. The IFN- $\gamma$ level significantly increased $(P<0.001 ; P<0.01)$ at each days of the experiment (Fig. 2d). A. suum infection modulated the IFN- $y$ production in mice without the intoxication only during the $1^{\text {st }}$ week p.i. Mice intoxicated with $\mathrm{Cd}$ maintained the IFN-y production and values remained high throughout the experiment $(P<0.01)$.

\section{Mercury and Ascaris suum infection}

\section{Parasite burden}

The total numbers of larvae in mice intoxicated with $\mathrm{Hg}$ (Table 2) were significantly reduced in the liver at day 4 p.i. and in the lungs at day 7 p.i. Mice intoxicated with $\mathrm{Hg}$ were extremely cachectic (unpublished data).

\section{IL-5 and IL-10 production}

The IL-5 production was elevated $(P<0.0001)$ at the $3^{\text {rd }}$ week of $\mathrm{Hg}$ intoxication and $A$. suum increased its production on $2^{\text {nd }}$ week p.i. (Fig. 3a). Hg intoxication maintained higher level of IL-5 ( $P<0.05$; $P<0.01$ ) also after the $A$. suum infection during the first week p.i. However, a decrease in IL-5 level $(P<0.001)$ on $2^{\text {nd }}$ week p.i. was detected. The production of IL-10 (Fig. 3b) was significantly stimulated after the $\mathrm{Hg}$ intoxication $(\mathrm{P}<0.05 ; \mathrm{P}<0.001 ; \mathrm{P}<0.0001)$. A. suum infection increased the IL-10 production with a progressive increase until $2^{\text {nd }}$ week p.i. A similar growth trend in IL-10 synthesis was found in mice intoxicated with $\mathrm{Hg}$ and subsequently infected with A.suum. The IL-10 level in infected and intoxicated was higher $(P<0.001 ; P<0.01)$ when compared with mice without the $C d$ intoxication.

\section{TNF- $\alpha$ and IFN- $y$ production}

$\mathrm{Hg}$ intoxication increased the TNF- $\mathrm{a}$ production $(\mathrm{P}<0.001$; $P<0.0001$ ) from week 3 until the end of the experiment (Fig. 3c). A. suum infection that inhibited TNF-a level below uninfected control from day 7 p.i. suppressed also the TNF-a production in mice intoxicated with $\mathrm{Hg}$ within $1^{\text {st }}$ week post $A$. suum infection. $\mathrm{Hg}$ increased the IFN-y production after 3 weeks of intoxication (Fig. 3d). A. suum infection increased the IFN-y production in mice without intoxication during the first week p.i. In mice intoxicated with $\mathrm{Hg}$ and subsequently infected very low concentrations of IFN-y were found.

\section{Discussion}

Ability to accumulate heavy metals in tissues is associated with modulation of the host immune response what can explain positive or negative role of contaminated environment on the outcome of 
parasitic infection. The consequence of this interaction on small mammals living in terrestrial ecosystems has great bioindicative value for the assessment of environmental contamination. Current immunological analysis about the effect of heavy metals in model parasitic zoonosis is pilot study examining parasite-host interactions under heavy metal stimulus. Under such conditions, both the host and parasite are susceptible to the pathogenic effects of toxicants which may result in detrimental changes to their immunological and physiological responses. To this point it is not known how combination of contaminated environment and parasitism can influence development of immune response where regulatory (helper lymphocytes, cytokines) and effector (macrophages) components are important in the host defence against parasite. Specifically when these immune cells are also target structures for the heavy metals (Šoltys et al., 1997; Valko et al., 2005; Pollard \& Kono, 2013).

Mice are monogastric animals in which the liver and kidneys serve as detoxification organs that help to eliminate toxic waste metabolites from the body. Heavy metals can enter the host organism either through the plant food or water contaminated with toxic substances from nearby industrial complexes (Hančulák et al., 2005, $2006,2011)$. An accumulation of heavy metals in tissues of small mammals reflects an actual environmental contamination. Heavy metal distribution in mice organs differs and depends on specific metal affinity to different tissues. The liver belongs to main detoxification organ and also plays a key role in the host defence during A. suum migration. In our study the accumulation of lead in tissues reached the maximum in the acute phase of the infection (week 3) and later its content in the liver, kidneys or muscles decreased. Cadmium distribution in mice significantly preferred kidneys and $\mathrm{Cd}$ concentration was time dependent. $A$. suum infection prevented accumulation of $\mathrm{Cd}$ in the kidneys and liver. Since the $\mathrm{Cd}$ interacts with host enzymes (Swiergosz-Kowalewska, 2001) we can hypothesize that cadmium was exhausted during increased metabolism and following parasite infection. Cd had immunomodulative effect on the host and stimulated its defence mechanisms what resulted in the reduction of parasite burden. Also in mice intoxicated with $\mathrm{Hg}$, the kidneys were a primary organ for metal accumulation. Its maximal concentration peaked at week 3 and gradually declined towards week 5 . The $A$. suum infection did not affect mercury distribution.

We found that the differences in parasite infection intensity were dependent on particular heavy metal involved. In summary a non-significant increase parasite burden in mice intoxicated with $\mathrm{Pb}$ was recorded. In contrast to this observation a big parasite reduction in $\mathrm{Cd}$ intoxicated mice was observed. Also a low numbers of Ascaris larvae were found in $\mathrm{Hg}$ intoxicated mice. Moreover these animals were extremely cachectic and probably their extreme weakness limited the development of parasitic infection. The differences in parasite burden may well be explained by a different immunotoxic effect of heavy metals on the host cytokine responses. Lead intoxication lead to the development of Th2 type of response where, to some extent, an increase in production of anti-inflammatory cytokine IL-10 and IL-5 from week 2 was observed. The Th1 response was suppressed after the $\mathrm{Pb}$ administration. IFN- $y$ and TNF- $\alpha$ concentrations were greatly below the control levels. Our data correlates with results of Hemdan et al. (2005) who found that low doses of lead suppressed Th1 response (reduced expression of IFN- $\gamma, I L \beta-1$ and TNF- $\alpha$ ) and increased IL-4 and IL-10 production. Heo et al. (1998) presented similar results where addition of $\mathrm{PbCl}_{2}$ to the cell cultures caused a significant inhibition of IFN- $\gamma$ production and increased production of IL-4. García-Lestón et al. (2012) assessed cytokine profiles in workers exposed to the lead who showed significant decrease in $\mathrm{IL}-4, \mathrm{TNF}-\alpha$ and IFN- $\gamma$, and they observed a substantial increase in IL-10 level. Similarly El-Gharabawy et al. (2013), in Egyptian paint workers, detected a significant elevations in serum IgE as well as IL-4, IL-6 and distinctive reduction in IL-10 level.

In our study mice $\mathrm{Cd}$ intoxication lead to the development of Th1 type of immune response. Cadmium significantly stimulated the production of IFN- $\gamma$ cytokine throughout the experiment. The IL-10 and TNF-a were slightly up-regulated and IL-5 production was not affected by $\mathrm{Cd}$. Comparable Th1 polarisation during $\mathrm{Cd}$ administration was described by Marth et al. (2000). In this study low cadmium doses $(5 \mu \mathrm{mol} / \mathrm{l})$ stimulated the production of proinflammatory IL-1 $\beta$, TNF- $\alpha$ and IL-6. Meanwhile high Cd doses (50 $\mu \mathrm{mol} / \mathrm{l})$ increased the IFN-y level. Hemdan et al. (2006) confirmed the different effect of cellular activation on Th1/Th2 cytokine activity followed by $\mathrm{Cd}$ intoxication where the Th1 polarisation induced by bacterial antigen predominated over the Th2 modulating effect of cadmium.

Mice mercury intoxication did not show a clear cut between Th1 or Th2 type of response. Mercury significantly stimulated the production of IL-10 what also affects the synthesis of Th1 cytokines. Correspondingly, the other authors confirmed that $\mathrm{Hg}$ affects immune function in human cells by dysregulation of cytokine signalling pathways. Gardner et al. (2009) found that $\mathrm{Hg}$ caused an increase in pro-inflammatory cytokine release (IL-1 $\beta, T N F-a, I F N-\gamma)$, but subsequently up-regulation in IL-4 and down-regulation in IL-10 was observed. Large and uncontrolled production of inflammatory cytokines plays a key role in aetiology and development of autoimmune diseases (Hu et al., 1999). Also it can alter the host-pathogen interactions or increase the susceptibility to diseases (Gardner et al., 2010). Hemdan et al. (2007) in vitro demonstrated differences in Hg effect on the Th1/Th2 balance after different cells stimulation. Authors stated that a low dose of $\mathrm{Hg}$ turns up the immune response towards Th2 type in the case of absence of inflammatory component, but not in the case of Th1 immune response induced by bacterial antigen.

In our experiment mice intoxicated with heavy metals and subsequently infected with $A$. suum showed deviations in cytokine production in comparison with the non-intoxicated mice. The production of IL-5 cytokine was more influenced by $A$. suum infection than by metal intoxication where the up-regulation of $\mathrm{IL}-5$ in $\mathrm{Pb}$ 
intoxicated mice was probably caused by higher parasite burden. The early production of IL-5 might be associated with the immunopathology induced by the first migrating larvae and the protective eosinophil-mediated immune response (Behm \& Ovington 2000; Gazzinelli-Guimarães et al., 2013). Except the mercury the Th2 immunomodulative effect of $A$. suum on the production of a regulatory IL-10 cytokine was stronger. Meanwhile no differences in IL-10 production were recorded in people in ascariasis endemic areas (Cooper et al., 2000). Turner et al. (2003) also found a negative correlation between IL-10 and infection intensity.

The Th1 immune response is effective in eliminating of tissue stages of these parasites (Mulcahy et al., 2005). The Th1 immune response was more suppressed by $\mathrm{Pb}$. Both TNF- $a$ and IFN- $y$ did not reach the levels detected in non-intoxicated mice. Mercury intoxication and subsequent $A$. suum infection profoundly inhibited the synthesis of IFN-y. However the TNF-a remained elevated. Another study recorded increased TNF levels in the lung on days 10 and 12 after the $A$. suum infection. This could be related with increased number of macrophages (a source of TNF) at the inflammatory sites (Gazzinelli-Guimarães et al., 2013). In our study the high level of TNF-a after $\mathrm{Hg}$ intoxication probably together with IL-1 $\beta$ and IL-6 (Broekhuizen et al., 2005) caused a massive inflammatory response what resulted in mice weakness and cachexia.

Only cadmium intoxication stimulated the IFN-y production and subsequent parasite infection did not change significantly the IFN- $y$ level. Up-regulation in TNF-a induced by cadmium was turned over into suppression after the infection. Reduced number of $A$. suum larvae in mice intoxicated with $\mathrm{Cd}$ suggests the importance of IFN-y in larval destruction through macrophage activation (Jalčová \& Dvorožnáková, 2014). We suppose that early stimulation of IFN-y production activated hepatic inflammatory mechanisms what contributed to the anti-parasite protection where hepatic/post-hepatic factors in protection against larval Ascaris migration from the liver to the lungs are also involved (Lewis et al., 2007; Holland, 2009).

The protective immune response against the gastrointestinal helminths is characterized by Th2 response. Individuals that can naturally upregulate the Th2 response during larval migration may cause suppression of the Th1 immune response what results in an increased susceptibility to the infection. This is supported by Th2 modulation of the host immunity with heavy metals. Another possibility is that viable migrating larvae lead to the preferential stimulation of the Th2 response leading to the parasite evasion and increasing their survival by further down-regulation of the Th1 type of parasite specific responses (Lewis et al., 2006).

$\mathrm{Pb}$ and $\mathrm{Hg}$ modulated murine immune response toward the Th2 or mixed Th2/Th1 type that dominated after the subsequent $A$. suum infection and caused a more intensive development of parasite infection in $\mathrm{Pb}$ intoxicated mice. Cd stimulated the IFN-y production and Th1 immune response what resulted in reduction and destruction of larvae in the liver of intoxicated mice. Our study confirmed a metal-specific modification of host immune system. We found changes in the Th1/Th2 cytokine profile that plays an important role in the establishment of successful immune reactions against the parasite infection. Lead pollution can increase parasitism. Host Th1 defence mechanisms were negatively suppressed and additionally larval migration was not controlled by the host. In contrast cadmium stimulated the Th1 response what was affiliated with a more destructive effect on the larvae and restricted development of parasite infection. Nevertheless mercury pollution can also decrease parasitism but this was probably caused by the host physiological status, when weak and cachectic mice organisms with mixed Th2/Th1 cytokine production were not able to offer good conditions for the development of parasite infection. Heavily infected hosts are likely to suffer greater morbidity and mortality what make a greater presence of infective stages in the environment (Holland, 2009). Our results suggest the different effects of particular heavy metals on parasite host status in the polluted areas and on different risks of parasite infection depending on heavy metal pollution.

\section{Acknowledgements}

This work was supported by the Operational Programme Research and Development, funded by the European Regional Development Fund under the Project "INFEKTZOON - Centre of Excellence for Animal Infections and Zoonoses (ITMS-26220120002)".

\section{References}

Behm, C.A., Ovington, K.S. (2000): The role of eosinophils in parasitic helminth infections: insights from genetically modified mice. Parasitol. Today, 16(5): 202 - 209. DOI: 10.1016/S01694758(99)01620-8

Betson, M., Nejsum, P., Bendall, R.P., Deb, R.M., Stothard, J.R. (2014): Molecular epidemiology of ascariasis: a global perspective on the transmission dynamics of Ascaris in people and pigs. J. Infect. Dis., 210(6): 932 - 941. DOI: 10.1093/infdis/jiu193

Boes, J., ERIKSen, L., Nansen, P. (1998): Embryonation and infectivity of Ascaris suum eggs isolated from worms expelled by pigs treated with albendazole, pyrantel pamoate, ivermectin or piperazine dihydrochloride. Vet. Parasitol., 75(2-3): 181 - 190. DOI:10.1016/S0304-4017(97)00197-0

Broekhuizen, R., Grimble, R.F., Howell, W.M., Shale, D.J., Creutzberg, E.C., Wouters, E.F., Schols, A.M. (2005): Pulmonary cachexia, systemic inflammatory profile, and the interleukin 1 beta -511 single nucleotide polymorphism. Am. J. Clin. Nutr., 82(5): $1059-1064$

Cooper, P.J., Chico, M.E., Sandoval, C., Espinel, I., Guevara, A. Kennedy, M.W., URban, J.F. JR, Griffin, G.E.J., Nutman, T.B. JR. (2000): Human infection with Ascaris lumbricoides is associated with a polarized cytokine response. J. Infect. Dis., 182(4): 1207 1213. DOI: $10.1086 / 315830$ 
DvorožñÁKovÁ, E., HuRníKovÁ, Z., KolodZIEJ-SoBocińSKA, M. (2011): Development of cellular immune response of mice to infection with low doses of Trichinella spiralis, Trichinella britovi and Trichinella pseudospiralis larvae. Parasitol. Res. 108(1): 169 - 176. DOI: 10.1007/s00436-010-2049-x

DVorožŇÁKovÁ, E., JalČovÁ, M. (2013): Cytokine response of mice to heavy metal intoxication and Ascaris suum infection. In: Cozma, V. (Ed.) 11th European Multicolloquium of Parasitology (EMOP), 25-29 July, 2012, Cluj Napoca, Romania. Medimond s.r.l., Bologna, Italy (ISBN 978-88-7587-669-2), pp. 25 -27

El-Gharabawy, R. M., El-Maddah, E. I., Oreby, M. M., Salem, H. S., RAMADAN, M. O. (2013): Immunotoxicity and pulmonary toxicity induced by paints in Egyptian painters. J. Immunotoxicol. 10(3): 270 - 278. DOI: 10.3109/1547691X.2012.714005

Flickinger, E. L., Nichols, J. D. (1990): Small mammal populations at hazardous waste disposal sites near Houston, Texas, USA. Environ. Pollut. 65(2): 169 - 180. DOI:10.1016/0269-7491(90)90182-C García-Lestón, J., Roma-Torres, J., Mayan, O., Schroecksnadel, S., Fuchs, D., Moreira, A. O., PÁsaro, E., Méndez, J., Teixeira, J. P., LafFON, B. (2012): Assessment of immunotoxicity parameters in individuals occupationally exposed to lead. J. Toxicol. Environ. Health A 75(13-15): 807 - 818. DOI: 10.1080/15287394.2012.690327

Gardner, R. M., Nyland, J. F., Evans, S. L., Wang, S. B., Doyle, K. M., Crainiceanu, C. M., Silbergeld, E. K. (2009) Mercury induces an unopposed inflammatory response in human peripheral blood mononuclear cells in vitro. Environ. Health Perspect. 117:1932 1938. DOI: 10.1289/ehp.0900855

Gardner, R. M., Nyland, J. F., Silva, A. I., Ventura, A. M., de Souza, J. M., Silbergeld, E. K. (2010): Mercury exposure, serum antinuclear/antinucleolar antibodies, and serum cytokine levels in mining populations in Amazonian Brazil: Across- sectional study. Environ. Res. 110: 345 - 354. DOI: 10.1016/j.envres.2010.02.001

Gazzinelli-Guimarães, P. H., Gazzinelli-Guimarães, A. C., Silva, F. N., Matı, V. L., Dhom-Lemos, L. de C., Barbosa, F. S., Passos, L. S., Gaze, S., Carneiro, C. M., Bartholomeu, D. C., Bueno, L. L., FujlWARA, R. T. (2013): Parasitological and immunological aspects of early Ascaris spp. infection in mice. Int. J. Parasitol. 43:697 - 706. DOI: 10.1016/j.ijpara.2013.02.009

Hančuĺák, J., Bobro, M., Brehuv, J., Slančo, P. (2005): Deposition of heavy metals from dust fallout in selected areas of Eastern Slovakia (In Slovak). Acta Montanistica Slovaca 10(1): 246 - 252 Hančulík, J., Bobro, M., ŠEstinová, O., Brehuv, J., Slančo, P. (2006): Mercury in the surrounding of old mining loads of Rudňany and Merník (In Slovak). Acta Montanistica Slovaca 11(2): 295 - 299 Hančul'ák, J., Fedorová, E., Šestinová, O., Špaldon, T., Matik, M. (2011): Influence of iron ore works in Nižná Slaná on atmospheric deposition of heavy metals. Acta Montan. Slovaca 16(3): 220 - 228 Hemdan, N. Y. A., Emmrich, F., Adham, K., Wichmann, G., Lehmann, I., El-Massry, A., Ghoneim, H., Lehmann, J., SACK, U. (2005): Dose-dependent modulation of the in vitro cytokine production of human immune compotent cells by lead salts. Toxicol. Sci. 86 (1): 75 - 83 . DOI: $10.1093 /$ toxsci/kfi177
Hemdan, N. Y. A., Emmrich, F., Sack, U., Wichmann, G., Lehmann, J., Adham, K., Lehmann, I. (2006): The in vitro immune modulation by cadmium depends on the way of cell activation. Toxicology 222(12): 37 - 45. DOI: 10.1016/j.tox.2006.01.026

Hemdan, N. Y. A., Lehmann, I., Wichmann, G., Lehmann, J., Emmrich, F., SACK, U. (2007): Immunomodulation by mercuric chloride in vitro: application of diferent cell activation pathways. Clin. Exp. Immunol. 148(2): 325 - 337. DOI: 10.1111/j.1365-2249.2007.03338.x Hemdan, N. Y., Abu El-SaAd, A. M., Sack, U. (2013): The role of $\mathrm{T}$ helper $(\mathrm{TH}) 17$ cells as a double-edged sword in the interplay of infection and autoimmunity with a focus on xenobiotic-induced immunomodulation. Clin. Dev. Immunol. 2013: Article ID 374769, 13 pages. DOI: 10.1155/2013/374769.

Heo, Y., Lee, W. T., LAWRence, D. L. (1998): Differential effects of lead and CAMP on development and activities of Th1-and Th2-lymphocytes. Toxicol. Sci. 43(2): 172 - 185. DOI: 10.1093/toxsci/43.2.172 Holland, C.V. (2009) Predisposition to ascariasis: patterns, mechanisms and implications. Parasitology 136(12): 1537 - 1547. DOI: 10.1017/S0031182009005952

Holmes, P., James, K. A., LeVy, L. S. (2009): Is low-level environmental mercury exposure of concern to human health? Sci. Total Environ. 408(2): 171 - 182. DOI: 10.1016/j.scitotenv.2009.09.043. Hu, H., Moller, G., Abedi-Valugerdi, M. (1999): Mechanism of mercury induced autoimmunity: both $\mathrm{T}$ helper 1 - and T helper 2-type responses are involved. Immunology 96(3): 348 - 357. DOI: 10.1046/j.1365-2567.1999.00671.x

JalČovÁ, M., DvorožŇÁkovÁ, E. (2014): Effect of heavy metal intoxication on macrophage metabolic activity of mice infected with Ascaris suum. Helminthologia 51(3): 171 - 180. DOI: 10.2478/ s11687-014-0226-7

JÄRUP, L. (2003): Hazards of heavy metal contamination. Br. Med. Bull. 68(1): 167 - 182. DOI: 10.1093/bmb/ldg032

Jomova, K., Valko, M. (2011): Advances in metal-induced oxidative stress and human disease. Toxicology 283(2-3): 65 - 87. DOI: 10.1016/j.tox.2011.03.001

Kutalek, R., Wewalka, G., Gundacker, C., Auer, H., Wilson, J., Haluza, D., Huhulescu, S., Hillier, S., Sager, M., Prinz, A. (2010): Geophagy and potential health implications: geohelminths, microbes and heavy metals. Trans. R. Soc. Trop. Med. Hyg. 104(12): 787 - 795. DOI: 10.1016/j.trstmh.2010.09.002

LAfFerty, K. D., KurIS, A. M. (1999): How environmental stress affects the impacts of parasites. Limnol. Oceanogr. 44(3, part2): $925-931$

Lewis, R., Behnke, J. M., Stafford, P., Holland, C. V. (2006) The development of a mouse model to explore resistance and susceptibility to early Ascaris suum infection. Parasitology 132(2): 289 - 300. DOI: 10.1017/S0031182005008978.

Lewis, R., Behnke, J. M., Cassidy, J. P., Stafford, P., Murray, N., Holland, C. V. (2007): The migration of Ascaris suum larvae, and the associated pulmonary inflammatory response in susceptible C57BL/6j and resistant CBA/Ca mice. Parasitology 134(9): 1301 1314. DOI: $10.1017 /$ S0031182007002582. 
Marth, E., Barth, S., Jelovcan, S. (2000): Influence of cadmium on the immune system. Description of stimulating reactions. Cent. Eur. J. Public Health, 8(1): $40-44$

Mulcahy, G., O'Neill, S., Fanning, J., McCarthy, E., Sekiya, M. (2005): Tissue migration by parasitic helminths - an immunoevasive strategy? Trends Parasitol., 21(6): 273 - 277. DOI: 10.1016/j. pt.2005.04.003

Ngui, R., Lim, Y.A., Chong Kin, L., Sek Chuen, C., Jaffar, S. (2012): Association between anaemia, iron deficiency anaemia, neglected parasitic infections and socioeconomic factors in rural children of West Malaysia. PLoS Negl. Trop. Dis., 6(3): e1550. DOI: 10.1371/ journal.pntd.0001550.

Pollard, K.M., Kono, D. H. (2013): Requirements for innate immune pathways in environmentally induced autoimmunity. BMC Med., 11(4): 100. DOI: 10.1186/1741-7015-11-100.

Šnábel, V., Taira, K., Cavallero, S., D’Amelio, S., Rudohradská, P., SAITOH, Y. (2012): Genetic structure of Ascaris roundworm in Japan and patterns of its geographical variation. Jpn. J. Infect. Dis., 65(2): $179-183$
ŠoltYS, J., BorošKovÁ, Z., DVorožŇ́́kOVÁ, E. (1997): Effects of concurrently administered copper and mercury on phagocytic cell activity and antibody levels in guinea pigs with experimental ascariasis. J. Helminthol., 71(4): 339 - 444

Swiergosz-Kowalewska, R. (2001): Cadmium distribution and toxicity in tissues of small rodents. Microsc. Res. Tech., 55(3): 208 - 222. DOI: 10.1002/jemt.1171

Tersago, K., De Coen, W., Scheirs J., Vermeulen, K., Blust, R., Van Bockstaele, D., Verhagen, R. (2004): Immunotoxicology in wood mice along a heavy metal pollution gradient. Environ. Pollut., 132(3): 385 - 394. DOI:10.1016/j.envpol.2004.05.029

Turner, J.D., Faulkner, H., Kamgno, J., Cormont, F., Van Snick, J., Else, K.J., Grencis, R.K., Behnke, J.M., Boussinesq, M., Bradley, J. E. (2003): Th2 cytokines are associated with reduced worm burdens in a human intestinal helminth infection. J. Infect. Dis., 188(11): 1768 - 1775. DOI: 10.1086/379370

Valko, M., Morris, H., Cronin, M. T. (2005): Metals, toxicity and oxidative stress. Curr. Med. Chem., 12(10): 1161 - 1208. DOl: $10.2174 / 0929867053764635$ 